Vol. 7(8), pp. 109-114, October, 2015

DOI: $10.5897 /$ IJWREE2015.0595

Article Number: 6838A3655749

ISSN 2141-6613

Copyright (C) 2015

Author(s) retain the copyright of this article

http://www.academicjournals.org/IJWREE
International Journal of Water Resources and Environmental Engineering

\title{
Assessment of contribution of major rivers inflow into the Dongting Lake, China
}

\author{
Telesphore Habiyakare ${ }^{1,2}$, Zhou Nianqing ${ }^{1 *}$ and Shen Xinping ${ }^{3}$ \\ ${ }^{1}$ Department of Hydraulic Engineering, Tongji University, Shanghai, China. \\ ${ }^{2}$ College of Science and Technology, University of Rwanda, Kigali, Rwanda. \\ ${ }^{3}$ Dongting Lake Water Resources Administration Bureau of Hunan Province, Changsha, China.
}

Received 30 June, 2015; Accepted 24 September, 2015

\begin{abstract}
The development associated with rapid industrialization and urbanization in Dongting Lake region has been more complex due to large water demand. Therefore study of water variation within the lake region is necessary for wetland protection, conservation and its sustainable management. In this study monitoring of different Hydrological Control Stations, the calculation and analysis was carried out over 2014 based on hydrological data. The results indicated that seasons are the typical main driving factor for water variation in the Dongting Lake; among the rivers, Xiang, Zi, Yuan and Li (also known as "Sishui") accounts for the major part of the inflow discharge into the lake, and therefore the overall trend is featured by a flow pattern from the southwest to the northeast (Chenglingji outlet). The results also indicated that the inflow discharge of major rivers ( $\mathrm{Li}$, Yuan, $\mathrm{Zi}$ and Xiang) dominates other rivers with approximately $58 \%$ input to the lake. On the other hands the discharge from Yangtze River is very low in dry season from December to February, and it becomes high up to the maximum level of 28500 $\mathrm{m}^{3} / \mathrm{s}$ during flood period from June to September which is approximately $42 \%$ of its annual inflow amount. Similarly, the annual input comparison between Yangtze River and major rivers showed that the large amount of inflow from Yangtze is observed from June to September, which accounted $76 \%$ of its total annual inflow to Dongting Lake. While the high inflow from major rivers is observed from May to August, which is estimated at $60 \%$ of the major rivers total annual inflow to Dongting Lake. This study has important practical significance for sustainable development of the water management in the Dongting Lake Basin.
\end{abstract}

Key words: Rivers, Dongting Lake, hydrological control stations, inflow discharge, Yangtze River.

\section{INTRODUCTION}

Dongting Lake has served as an essential buffer zone in times of flood, receiving excess water from Yangtze River; which is China's mightiest river and protecting many downstream. In recent decades however, the lake has shrunk dramatically, causing scientists to begin investigating the causes of these changes and their effects on one of the country's most important lakes. "150 years ago, it was $6,250 \mathrm{~km}^{2} .60$ years ago, it was 4,350 $\mathrm{km}^{2}$. Now, it is $2,625 \mathrm{~km}^{2 n}$, commented Jiang Yong, on the area of the lake. He also mentioned that, Mud and sand keep silting up in the south of the lake. Therefore the capacity of the lake storage is becoming smaller 
(Sean, 2010).

Flood and waterlogged disaster are frequent and serious, drought disaster occurs sometimes and meteorological disaster is diversified; finally, wetland resources have degraded and ecological balance has been badly shaken. Flood and waterlogged disaster in the Dongting Lake is due to the influence of artificial and natural factors such as abnormal atmospheric circulation and influence of land use change. Gradual loss of biodiversity and disturbances in ecological balance are due to the ecological succession from sand deposit to vegetation, over-fishing, over cultivation of beach area, water pollution and breaking of the return course of fishes by hydraulic structures (Mao and Xia, 2002).

Contribution of the lake in meeting the water demand of the region: Dongting Lake is a multi-use water body. It can be used for drinking water, flood control, shipping, waste disposal, fisheries, aquaculture and irrigation, and also can be used as a source of tourism and recreational activities. Rapid sedimentation of Dongting Lake causes difficulties for water storage and flood control. In the summer 1998, China experienced the worst flooding in 40 years along the Changjiang River and caused many damages (Spignesi, 2004). To reduce damages in the future in the Changjiang River Basin, the Chinese government adopted a new policy, "return land to the lake", which trends to increase the water storage to buffer the flood during flood season, over half million people living inside diked lands were relocated in the following five years and the lake area was increased by about $779 \mathrm{~km}^{2}$ (WRBHP, 2002).

The full development and utilization of water resources of this area reflect to the economic development and maintenance of ecological balance (Wan et al., 2012). The lake water was oligotrophic in 1960s, but the increased anthropogenic inputs into the lake have resulted in the deterioration of its water quality in many parts of the lake. In 2005, the arsenic and cadmium poisoning events took place in the Li River, a branch of the Xiang River, and in the lower reaches of the Xiang River, respectively (Hunan Water Administration, 2006). During the summer when water temperature becomes high enough to activate decomposition of organic matter, a great amount of inorganic nitrogen and phosphorus accumulated in the sediment regenerate into the water to supply with nutrients that prompts the phytoplankton growth. Enhanced production of organic substances in the water due to phytoplankton growth not only results in the water pollution, but also brings about serious environmental problems such as occurrence of water bloom, depletion of dissolved oxygen in the bottom water and drastic change in the aquatic biota or ecosystem. Dongting Lake Basin heavily populated with 10.08 million of people (EPD, 2010), it is also one of China's leading rice-producing regions; it is also known for cotton and fish production. Dongting Lake was China's largest lake during the Han dynasty.

Actually it is the China second-largest flesh water lake and it is divided into three parts; East Dongting Lake, South Dongting Lake and West Dongting Lake. It is inextricably linked with the Yangtze River in its Northern part through Songzi mouth, Taiping mouth, and Ouchi mouth of the Yangtze River runoff bleeder, and has four river system supply the "Li, Yuan " and "Zi, Xiang" river in Eastern part and Southern part respectively. The Dongting Lake joins again the Yangtze River at its outlet at Chenglingji (Du et al., 2001). The rich sediment of the marshland attracted farmers, and several embankments were built to keep out the Yangtze River and to gain more farmland. Unfortunately, silting of mud and sand in the lake, in addition to the anthropogenic environmental transformations in the lowland areas, reduced the lake area and its storage capacity and caused rapid deterioration of the lake's flood diversion and flood storage functions. This diminishing capacity increased the occurrence of flood disasters, mainly because of the rupture of embankments. Until 1998, the lake had 228 embankments and was surrounded by a farmland area of 0.34 million ha. After a disastrous flood in 1998 that took a death tool of 3,656 deaths, made 378,000 persons homeless, and resulted in an economic loss of US $\$ 737$ million, the State Council of the People's Republic of China formulated a policy, the Return Land to Lake Program, to prevent flooding (Chen, 2002).

Therefore the objectives of this study were to identify Hydrological Control Stations, calculation of water inflow and outflow to the lake and yearly contribution of major rivers in order to estimate seasonal water variation in the lake region, which is important for its sustainable use and management.

\section{METHODOLOGY}

\section{Study area description}

Dongting Lake Figure 1, the second largest fresh water lake in China, lies in the middle reaches of the Yangtze River between $28^{\circ}$ $30^{\circ} 00^{\prime}$ Latitude and $111^{\circ} 00^{\prime}-113^{\circ} 30^{\prime}$ Longitude Figure 2. It is fed by the Yangtze River via three outfalls (Songzi, Taiping and Ouchi), distributary channels, in the north; the Li River and Yuan River in the west; and the $\mathrm{Zi}$ and Xiang Rivers in the south. Floods are discharged into the lower Jingjiang reaches of the Yangtze River via the unique outlet at the Chenglingji hydrological station (Xue et al., 2012). The lake plays very important roles in maintaining water resources of Yangtze River and aquatic ecosystem equilibrium (Yang et al., 2007). The main flood season is from June to September and the lake wetland is inundated during this period. The lake water level decreases gradually and goes into the dry season from October. From April of next year, the water level rises again due to the flooding. The water level of Dongting Lake fluctuates greatly, about 12.9 m on average from 1955 to 2008 , in a year. Dongting Lake also provides habitat for many protected species. The 3 natural wetland reserves, East, South and West Dongting Nature Reserves in this area are all recognized Ramsar sites, (Ramsar, 2005). 


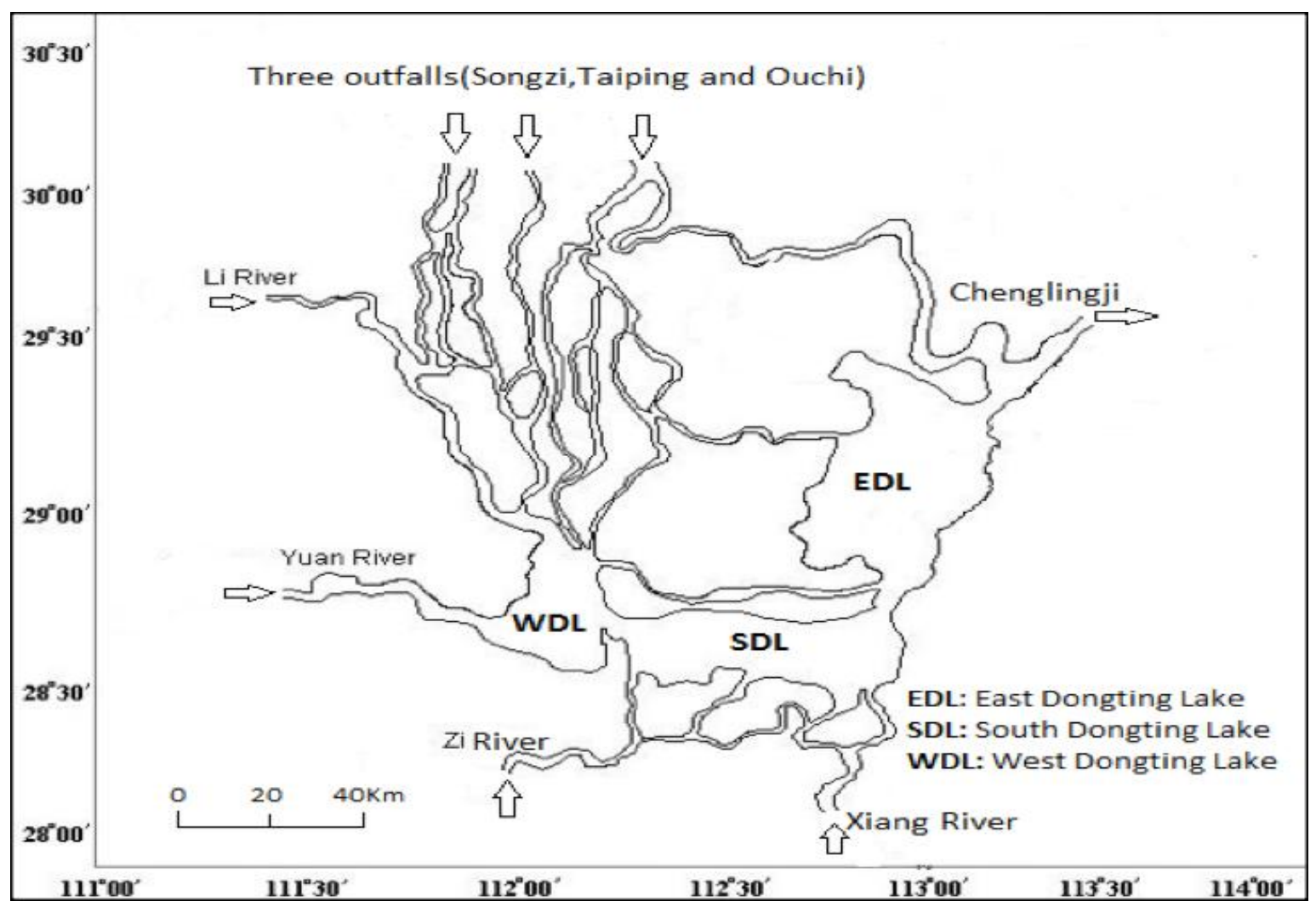

Figure 1. Dongting Lake rivers network system.

Table 1. Discharge at intake of the lake and outet of the lake in 2014.

\begin{tabular}{clll}
\hline River number & River name & Station & Annual discharge at intake $\left(\mathbf{m}^{\mathbf{3}} / \mathbf{s}\right)$ \\
\hline 1 & Songzi & Songzi & 318,881 \\
2 & Taiping & Gongan & 478,332 \\
3 & Ouchi & Shishou & 637,762 \\
4 & $\mathrm{Li}$ & Shimen & 152,500 \\
5 & Yuan & Taoyuan & $808,067.6$ \\
6 & Zi & Taojiang & 305,793 \\
7 & Xiang & Xiangtan & 724,461 \\
8 & Chenglingji & Chenglingji (outlet) & $3,164,048$ \\
\hline
\end{tabular}

\section{Primary data review and compilation}

In this study, the observation data from Dongting Lake Water Resources Administration Bureau of Hunan Province were used and 7 rivers from 1 to 7 (Songzi, Taiping,Ouchi, Li, Yuan, Zi, Xiang) respectively were taken into account Figure 3 . The water from Yangtze River flows into the West Lake through 3 outfalls (Songzi, Taiping and Ouchi) were collected at Songzi, Gongan and Shishou station respectively, and the flow from outlet in the Northern corner of East Lake at Chenglingji station as well as major rivers inflow to the lake: the Xiang, $\mathrm{Zi}$, Yuan and $\mathrm{Li}$ observation data were also collected at Xiangtan, Taojiang, Taoyuan and Shimen respectively. In This paper, Daily discharge at 8: 00 AM from above Hydrological monitoring stations were used to calculate and analysis of water inlet and outlet of the lake without considering regional rainfall. From graphical analysis, the total annual inflow from Yangtze River and four major rivers were tabulated in Table 1 after compiling the daily data. This paper will also concentrate on comparison of inflow and outflow and provide annual seasonal discharge variation within Dongting Lake.

\section{RESULTS AND DISCUSSION}

The data from monitoring stations (as shown the Figure 4) were collected and analyzed. It consists of 3 outfalls as inflow from Yangtze River and inflow from other four 


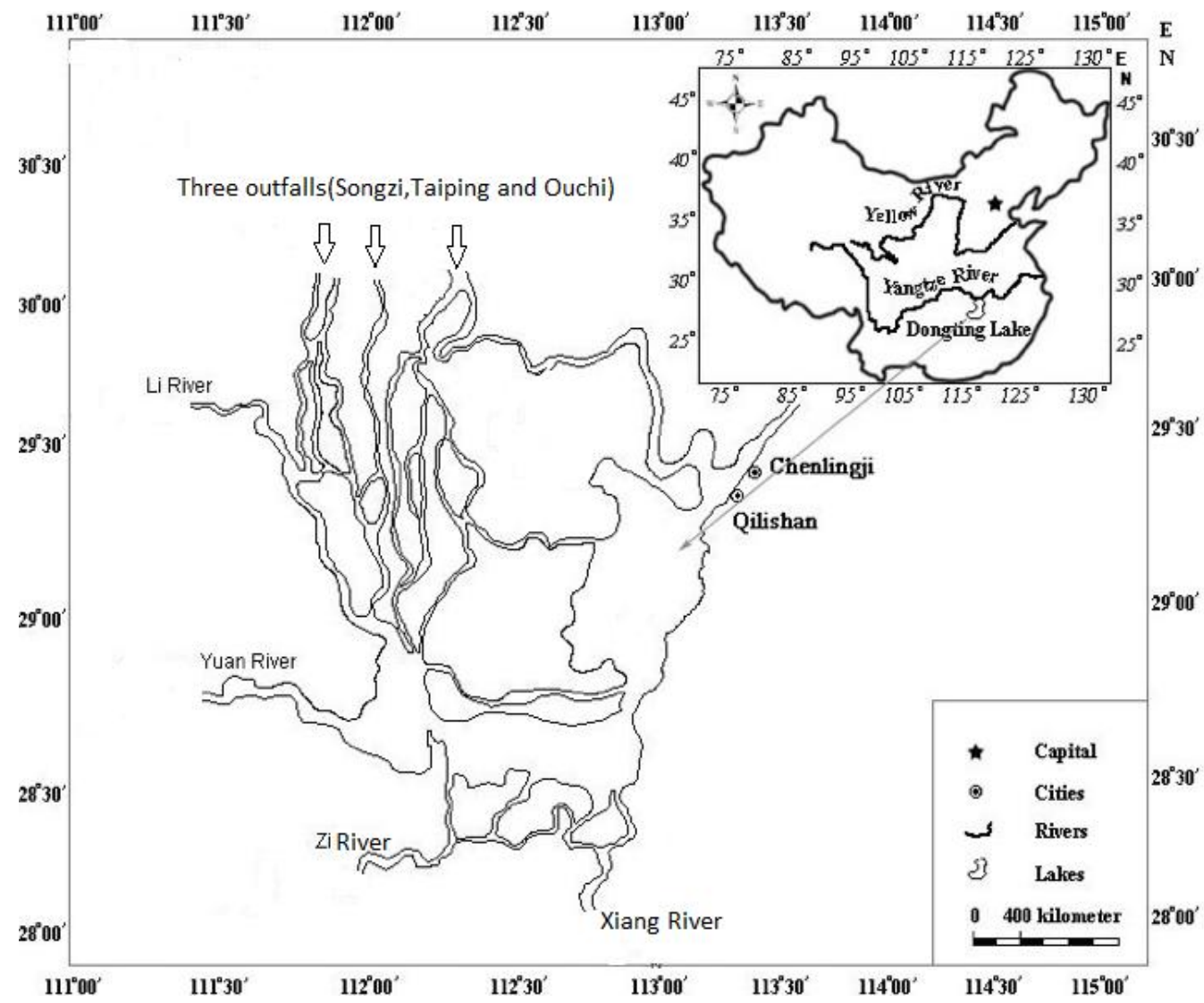

Figure 2. Dongting Lake location in China.

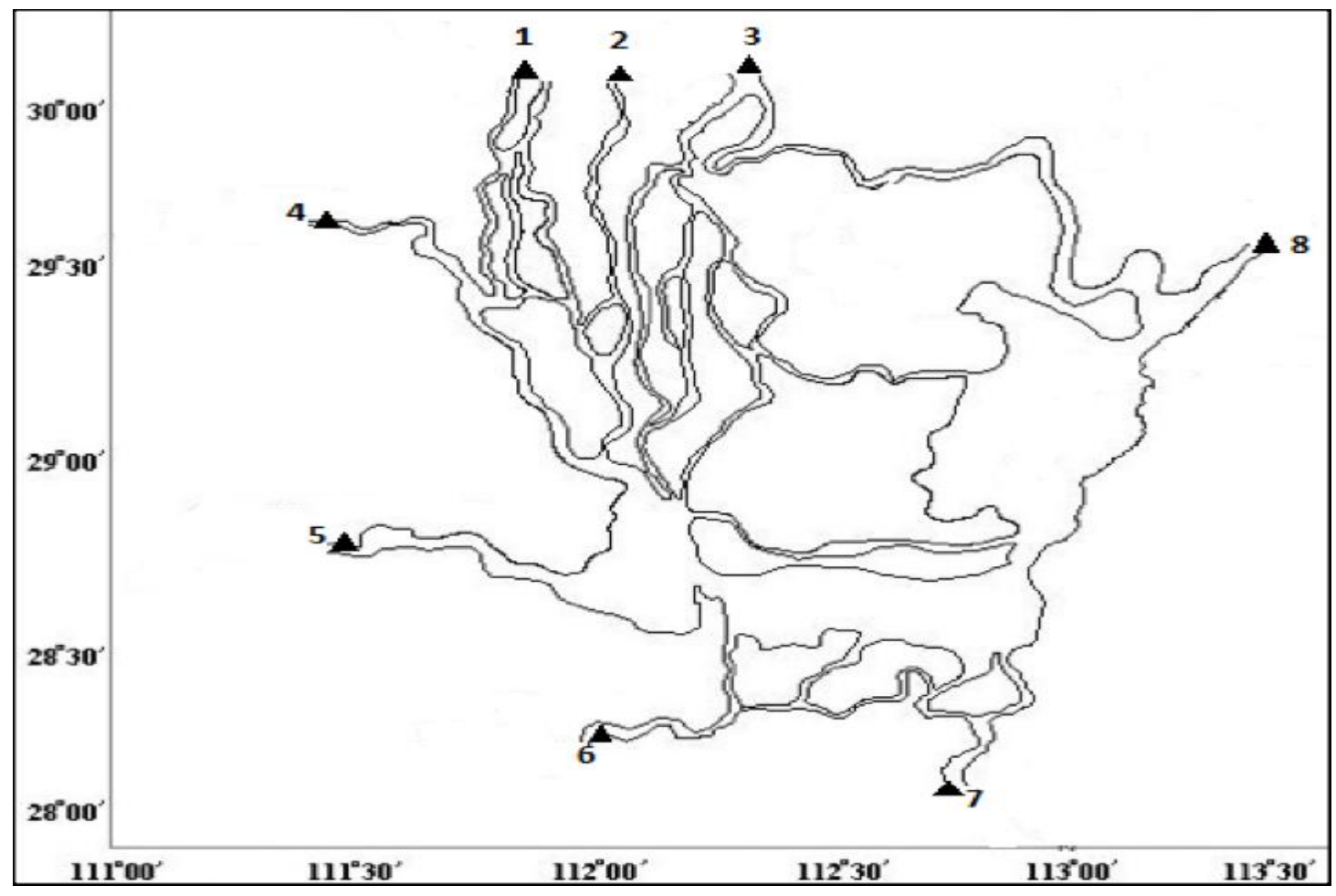

Figure 3. Location of considered monitoring stations for rivers. 


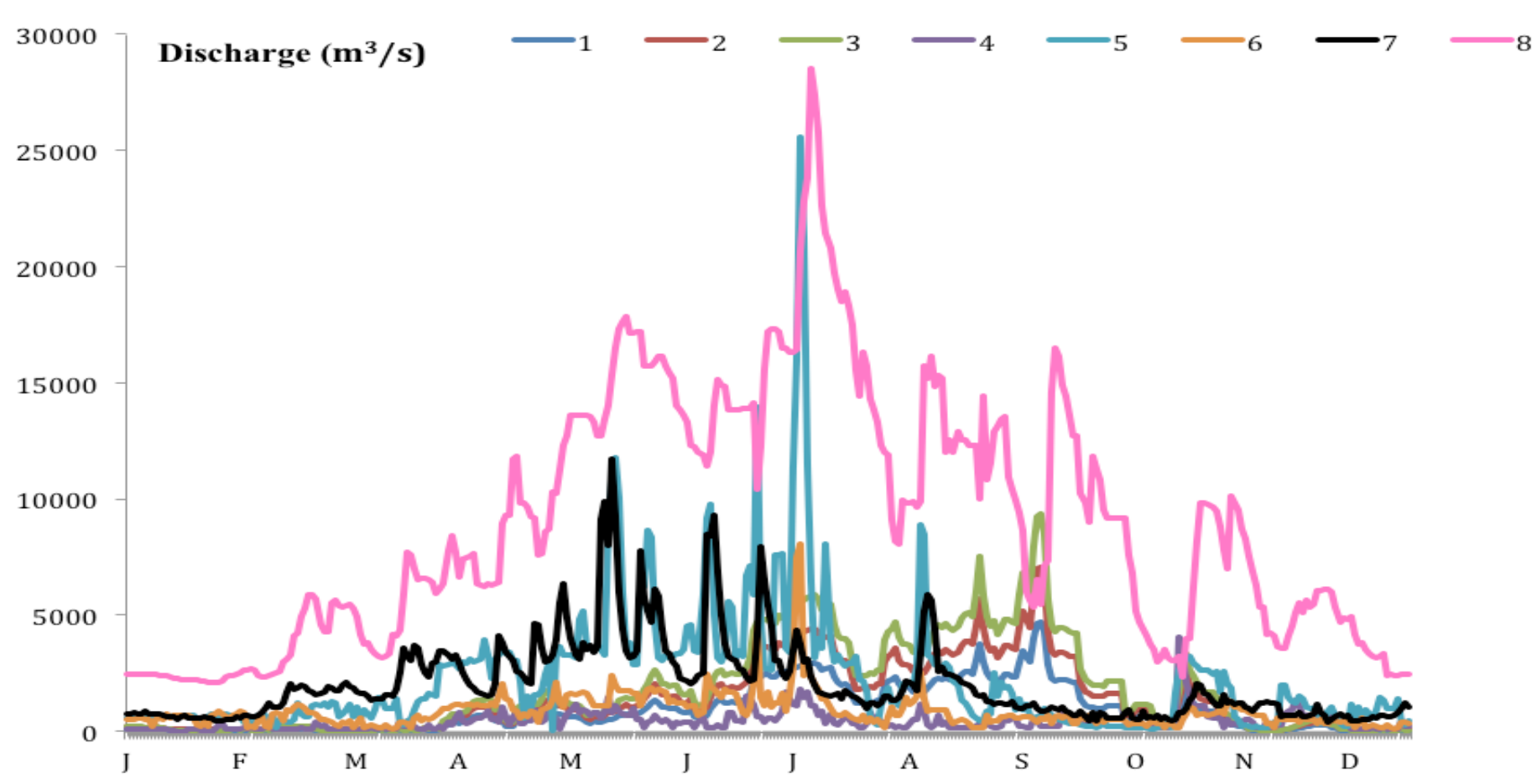

Figure 4. Annual discharge variation of the rivers in Dongting Lake in 2014.

rivers (Yuan River, Zi River, Xiang River and Li River) system.

From the Figure 4, the total inflow discharge of rivers is estimated to be $3.4 \times 10^{6} \mathrm{~m}^{3} /$ year. Hence, it is clear that the flood season of rivers 1 to 3 from Yangtze River is between July and October whereas the rivers 4 to $7(\mathrm{Li}$, Yuan, $\mathrm{Zi}$ and Xiang Rivers) is from May to August. In addition the input of major rivers ( $\mathrm{Li}$, Yuan, $\mathrm{Zi}$ and Xiang) dominates other rivers with approximately $58 \%$ of the total input though rivers. On the other hands the discharge from Yangtze River is remain very low in dry season from December to February, and it becomes high up to the maximum level of $28500 \mathrm{~m}^{3} / \mathrm{s}$ during flood period from June to September which is approximately $42 \%$ of the annual inflow amount. Similarly, the annual variation of the total inflow and outflow discharge in 2014 is indicated in Figures 5 and 6.

The annual contribution of the inflow from Yangtze River and four major rivers ( $\mathrm{Li}$, Yuan, $\mathrm{Zi}$ and Xiang) was calculated. It is clear from the Figure 6 that the high inflow from Yangtze River is observed from June to September, which is accounted $76 \%$ of its total annual inflow to Dongting Lake. While the high inflow from major rivers was observed from May to August, which was estimated at $60 \%$ of the major rivers total annual inflow to Dongting Lake. Similarly, the Figure 5 indicated that the total inflow was high from May to August compare to the total outflow, this was due to the flood season in the region, and the inflow reduced from November to March compare to the outflow.

\section{Conclusions}

(i) The overall inflow to the Dongting Lake from the river 1 to 7 respectively flowing from the North of the lake to Southwest and then East North of the lake (Chenglingji outlet). This flows into Dongting Lake was the main driving factors related to water level variation and seasonal characteristics, and four major rivers (Xiang, Zi, Yuan and $\mathrm{Li}$ ) occupy a major part of inflow into the lake Dongting as shown in Figure 6.

(ii) From Figure 5, it is clear that the total inflow is high from May to August compare to the total outflow; it reached $51790 \mathrm{~m}^{3} / \mathrm{s}$ in July, this was due to the flood season in the region, and the inflow reduced from November to March compare to outflow. Therefore the water level in Dongting Lake was affected and that might cause the lake storage capacity crisis, the loss of biodiversity, Dongting Lake wetland degradation and biodiversity loss. As the region is known to be industrial area, agricultural activities with high population, to meet the water demand is critical issue. Hence, the strategies for water regulation should be put in place and maintained.

The water movement process of Dongting Lake in 2014 is then calculated using the monitoring data stations. The inflow extent in Dongting Lake fluctuates with the season. The inflow extent changes rapidly along seasonal variation, especially in the beginning of flood season. In dry season, the water inflow is mainly reduced and inflow extent reaches the yearly minimum. The Lake received a 


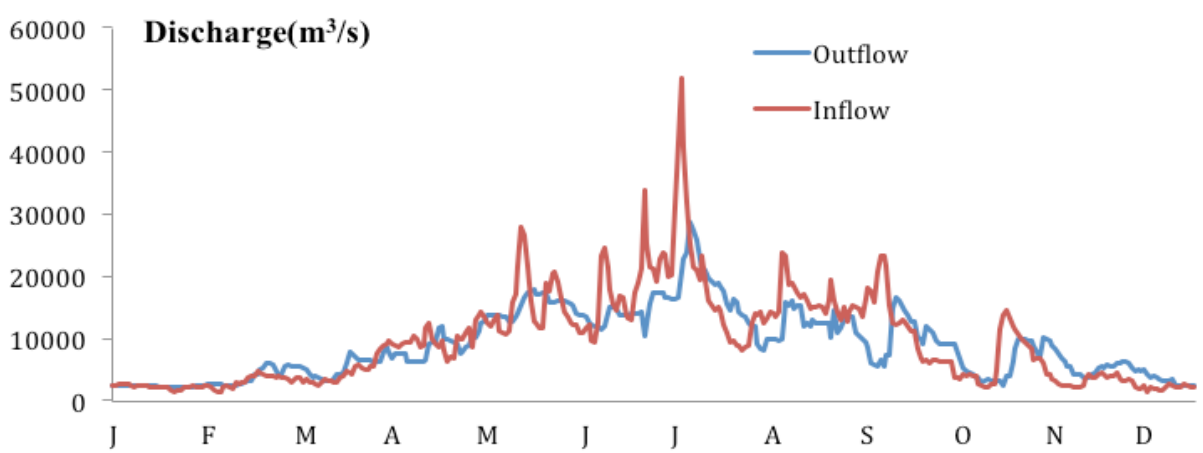

Figure 5. Dongting Lake annual inflow and outflow discharge of rivers in 2014.

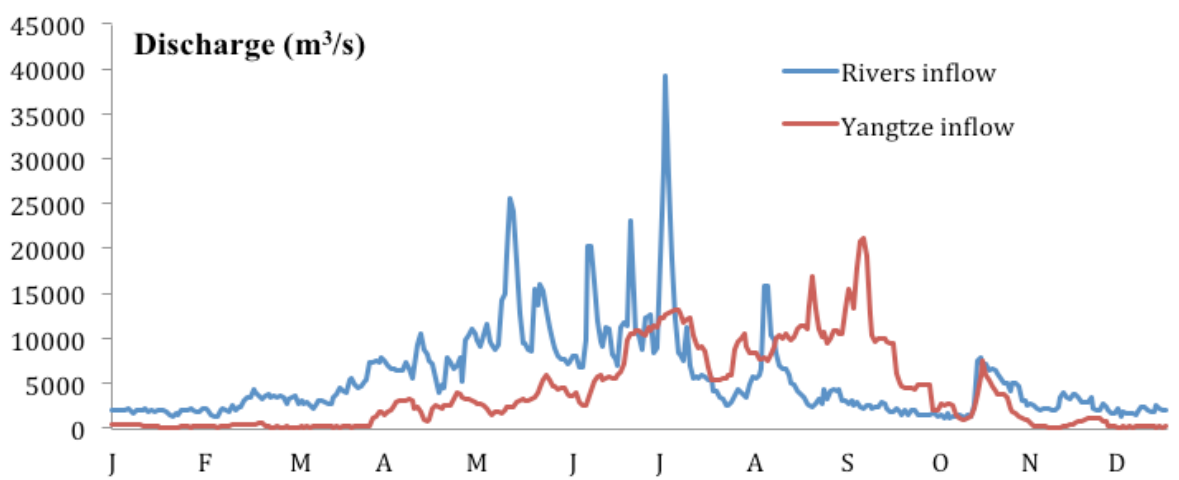

Figure 6. Annual inflow from Yangtze River and major rivers to Dongting Lake in 2014.

large amount of water in flood season and the maximum of inflow extent reaches. After the flood season, the lake exposes again with the gradual decrease of water inflow.

\section{Conflict of Interest}

The authors have not declared any conflict of interest.

\section{ACKNOWLEDGMENTS}

This study was supported by The National Science Fund of China (41272249), Research Fund for the Doctoral Program of Higher Education of China (20110072110020). Also, many thanks to the Chinese Government for a great opportunity to study in China.

\section{REFERENCES}

Chen ZJ (2002). Relationship between Three Gorges Project and the Dongting Lake [in Chinese]. Economic and Technical Committee of Hunan Provincial Political Consultative Conference. Changsha (P.R. China): Hunan Science and Technology Press, pp. 9-10, 259-260, 305.

Du Y, Cai S, Zhang X (2001). Interpretation of the environmental change of Dongting Lake, middle reach of Yangtze River, China, by
$210 \mathrm{~Pb}$ measurement and satellite image analysis Geomorphology, 41(2):171-181.

EPD (2010). Sino-norvegian Dongting Lake project,September. Hunan province.

Hunan Water Administration (2006). Urgent inform on further strengthening water resources management of Xiangjiang River drainage area. http://www.hnwr.gov.cn/news/html/2006/01/2002010914302 6-1.htm (in chinese).

Mao DH, Xia J (2002). Ecological and Environmental Problems and Their Causing Mechanisms in Dongting Lake Wetland. J. Glaciol. Geocryol. 24(4):444-451.

Ramsar CB (2005). The annotated Ramsar list of wetlands of international importance: China. http://ramsar.rgis.ch/cda/en/ramsardocuments-list-anno-china/main/ramsar/1-31218\%5E16477_4000_0. Accessed on 23 June 2015.

Sean G (2010). Pulitzer center China's Wetland Crisis, Dongting Hu: A Lake in Flux, Hunan Province,China. Available from http://pulitzercenter.org/blog/untold-stories/dongting-hu-lake-flux.

Spignesi SJ (2004). Cathographe: The 100 Greatest Disasters of All Time. New York: Citadel Press.

Wan XY, Zhong PA, Chen X, Dai L, Jia BY (2012). Computer Simulation of Flood Scheduling in Large Scale Flood Control Systems. Procedia Engineering 29:3267-3275.

WRBHP (2002). Division, Migration and construction in Dongting Lake in Hunan Province(in chinese): Water Resources Bureau of Hunan Province.

Xue LQ, Hao ZC, Liu XQ, Li YK (2012). Numerical simulation and optimal system scheduling on flood diversion and storage in Dongting Basin, China. Procedia Environ. Sci. 12:1089-1096.

Yang G, Wen L, Li L (2007). Yangtze Conservation and Development Report 2007, Beijing: Science Press. 